\title{
Value creation programmes: lessons from an early-stage implementation
}

\section{Bozward ${ }^{1}(1) \cdot$ M. C. Rogers-Draycott ${ }^{1}(\mathbb{C}$}

Received: 24 August 2020 / Revised: 7 September 2020 / Accepted: 13 September 2020 /

Published online: 26 September 2020

(c) Springer Nature Singapore Pte Ltd. 2020

\begin{abstract}
This paper explores the authors' efforts to design and deliver a Venture Creation Programme (VCP) at the University of Worcester between 2015 and 2017. The purpose of the paper is to present critical insights into the manner in which learning can be facilitated through VCPs using our own experiences as an example. The paper begins with a discussion of the authors' methodology before moving to a literature review addressing VCP's and related elements of entrepreneurial education best practice. It then shifts to a critical discussion of the authors' experiences based on insights, student and staff evaluations, and course data. In the process of conducting this review the authors found that good pedagogical design, in a VCP context, needs to focus on ensuring that academics promote constructive alignment between the curriculum that is 'taught', the teaching methods used, the learning environment chosen and the assessment procedures adopted. Only by minimising inconsistencies which link these factors will students' experiences of venture creation be fully engaging, promoting more effective, experiential and entrepreneurial development. This paper provides educators with an original and experiential insight into the design of a VCP programme and the pedagogical developments required for their successful implementation. There is considerable value herein for higher education institutions which want to design a new VCP, especially with reference to the curriculum design, experiential learning activities, types and methods of assessments and online learning environments for entrepreneurial students.
\end{abstract}

Keywords Venture Creation Programmes · Pedagogy $\cdot$ Enterprise · Entrepreneurship · Education

D. Bozward

David.bozward@rau.ac.uk

M. C. Rogers-Draycott

Matthew.draycott@rau.ac.uk

1 School of Business and Entrepreneurship, The Royal Agricultural University, Stroud Rd,

Cirencester GL7 6JS, UK 


\section{Introduction}

In September 2016 the University of Worcester became one of only a small number of institutions in the UK to launch a degree in entrepreneurship where venture creation was a central, assessed, element of learner participation.

There are a very limited number (Lackéus and Williams-Middleton 2011) of this type of 'true' Venture Creation Programme (VCP) globally. The authors define a VCP as a practice-oriented degree, combining the creation of a functioning venture with academic study (Lackéus and Williams-Middleton 2018). The term 'true' is used in this context to reflect the fact that there are numerous programmes which utilise competitions, tools and activities to simulate the experience of start-up processes (Pittaway and Edwards 2012; Scott et al. 2016), but these do not embed a mandate for the creation of a functioning venture at their core and/or make the development of this a requirement for the completion of the course.

As this was the newest 'true' Venture Creation Programme (VCP) in the UK, the authors felt that their experiences, the pedagogical challenges they faced and their reflections upon these, might make a useful contribution to the global literature, especially for anyone considering creating a similar programme. Therefore, the aim of this paper is to present the lessons learnt from this early-stage implementation to invigorate the discussion surrounding VCPs. The paper will do so by exploring a number of issues central to their successful implementation of the programme with a particular focus on the aforementioned pedagogical challenges, including curriculum design, teaching methods, experiential learning activities, types and methods of assessments, and online learning environments for entrepreneurial students.

\section{Methodology}

The process of education evaluation is an important part of the design and ongoing development of any course. The processes which govern this are well established (Molenda 2003) and described in numerous models of education instructional systems design (Clark 1995; Sortrakul and Denphaisarn 2009).

The range of methodologies used in evaluating education programmes is as diverse as the programmes themselves (Lewy 1977; Dressel 1980). The field of entrepreneurship education has been the focus of several publications including Fayolle et al. (2006), Vesper and Gartner (1997). These have shown that the evolution of students' attitudes and 'mindset' may be a better criteria than purely evaluating the economic impact or the number of businesses created.

As this is an early-stage evaluation of a programme, the methodology adopted should provide the ability to review the outcomes from a longitudinal perspective. Therefore, the authors adopted Donald Kirkpatrick's four levels of evaluation (Kirkpatrick and Craig 1970; Kirkpatrick 1975), which provides a framework that could be used in stages: 
1. Level 1 researches the reaction to the learning experience by the learner. This starts with the reaction and reflection of the programme by the students, understanding their likes and dislikes to all aspects of the programme. Therefore, the key questions of evaluation are what the student's reaction to the learning environment was.

2. Level 2 measures the learning by assessing what students have gained in the intended domain. What principles, facts, and techniques were learned? The key question at this level is whether the students achieved the desired learning objectives.

3. Level 3 develops an understanding of the changes in behaviour. What changes over time has the programme developed and solidified? This transfer of practice could be a direct or indirect result of a module or the overall programme. The key question at this level is whether the newly acquired skills, knowledge or attitude are being used by the learner after the learning event is completed.

4. Level 4 evaluates the results and the long-term impact of the programme graduate outcome. Kirkpatrick introduces the return on investment and the tallying of measurable long-term impacts to a company, gathering of data from the first three levels which correlates with things like graduation rates, job placement rates, and success rates in competitive scholarship or graduate school applications. The key question at this level is whether the student achieved the desired outcomes of the programme.

This investigation uses levels 1 and 2 of this framework, providing an evaluation tool in the first year of university education and enabling us to tailor the programme for the later years. Levels 3 and 4 could be used on completion of the 3 -year programme supporting the authors to gain a complete view of the VCP education intervention.

The paper presents data, insights and reflections collected during the first year in which the course ran, after this the staff running the course left, so further information cannot be presented. The subjects were under-graduate students on the VCP entrepreneurship degree who represented a broad range of ages (18-52), social economic backgrounds and a relatively equal mix of genders. The data used in the analyses were gathered from several sources including curriculum reviews, course meetings, student and staff reflections, meeting notes and other conversations.

It is important to note that reflection is used at a number of levels with students reflecting on their experiences in and around the curriculum, staff reflecting on their practice, the programme design and the students' development. Osterman and Kottkamp (1993) state that reflective practice is located within the older tradition of experiential learning and also the more recently defined perspective of situated cognition. Experiential learning theorists, including Dewey, Lewin, Piaget and Kolb's (1984) maintained that learning is most effective, most likely to lead to behavioural change, when it begins with experience and specifically problematic experience.

As part of the methodology of designing this programme we were faced with a complex pedagogical challenge which required us as entrepreneurship 
education practitioners to take the time to reflect on this experience. As part of our own reflective practice (Osterman and Kottkamp 1993) we wanted to use this as a framework for understanding individual and organisational opportunities for change.

\section{Our approach}

The aim of the VCP programme which the authors designed was to encourage students to learn 'for entrepreneurship' (QAA 2012, 2018) developing not only their knowledge and understanding of entrepreneurship and its related skills and abilities but also the practice of entrepreneurial activity. The vehicle for this was Gibb's (2002 p. 248) concept of 'learning by doing', contextualising and individualising learning experiences through start-up activity, so that these could synchronise with key moments in the students venture development lifecycle (Bozward and Rogers-Draycott 2017) to create moments of understanding (Rae 2003), from which critical insights into the students personal and professional development could be realised and reflected upon.

From the outset, the authors were clear that an unambiguous definition of entrepreneurship was important to act as a keystone of programme development, encouraging consistency and continuity which would underpin the course design and development. This was drawn from a board literature (Bruyat and Julien 2001; Fayolle 2007; Sarasvathy and Venkataraman 2011; Lackéus 2016; Shane and Venkataraman 2007; Moberg et al. 2012; QAA 2012) with the focus being on authors who had specifically addressed the action of venture creation, ideally in an educational context, and whose approaches (either practically or philosophically) were aligned to the goals for the programme (Fayolle 2007; Jones et al. 2014; Lackéus 2016); as a result, entrepreneurship would be defined as follows:

'Entrepreneurship is finding and developing opportunities to create value'.

This framed entrepreneurial activity in broad terms and focused it on the creation of 'value' (Lackéus 2016) a term which has been left deliberately ambiguous to give students an opportunity to develop ventures that encompassed a range of entrepreneurial action; not just the generation of revenue or profit.

The definition is also permissive rather than prescriptive, and it assumes nothing and allows students a freedom to explore their entrepreneurial selves without the constraint of a specific direction (Farmer, Yao and Kung-Mcintyre 2011). This meant that the experience of learning through the programme was most definitely not a 'spectator sport' (Tinto 2003), as students were actively challenged to participate in a cycle of venture creation, reflection and evaluation which informed their development and future activity.

This work formed the basis of the pedagogical methods applied across all the modules either directly as content, or indirectly through an influence on programme design and structure. 


\section{Programme pedagogy}

Biggs (1996, 2000) describes the duty of good pedagogical design as one of safeguarding that there are no inconsistencies between the curriculum we teach, the teaching methods we use, the learning environment we choose, and the assessment procedures we adopt. This he defined as constructive alignment. Previous pedagogical developments within VCPs have been researched and published by Gibb (1993, 2011), Ollila and Williams-Middleton (2011), Lackéus and Williams-Middleton (2015), Mwasalwiba (2010). These investigated the alignment of entrepreneurship education objectives, target audience, teaching methods and impact indicators, and found that greater focus should be put on the pedagogical alignment when setting or designing entrepreneurship education experiences.

To position the degree in an international best practice context, other VCPs were reviewed during the programme design (Lackéus and Williams-Middleton 2011, 2015). This work was used alongside the authors' definition, input from the business community, and the latest guidance from the subject benchmark statements (QAA $2012^{1}$; QAA 2018) to create the academic foundation for the course. It also provided a means for students and the wider community to understand and compare the context and characteristics of the programme against others around the world.

A staged learning narrative was then developed to support the students' entrepreneurial learning (Bozward, and Rogers-Draycott 2017) which drew on the work of Kuratko, Morris, and Schindehutte (2015) to break the entrepreneurial efforts into nine specific steps, each step comprising a number of focal competencies which would need to be met as part of the students' entrepreneurial development. A number of other researchers (Bird 1995; Man 2007; Rasmussen et al. 2011; Sanchez 2011) have found value in the concept of 'competence' to support the structuring of entrepreneurial education and assessment. Competence, in this form, has a wideranging conception encompassing knowledge, skills, attitudes, behaviours, work habits, abilities and personal characteristics (Le Deist and Winterton 2007). These focal competencies were then used to underpin the requirements of the curriculum and any assessments at each level within the degree. This framework formed the operational core of the degree, an easily identifiable map of key waypoints for educators and students which needed to be successfully navigated for progression to take place.

Based on this work, the BA (Hons) entrepreneurship programme focused on the active experience of business creation underpinned by relevant academic knowledge and the development of a broad base of entrepreneurial skills and capabilities. This was delivered through a mixture of dedicated sessions, simulations, work-based learning, enterprise events and interactions with entrepreneurs. The programme schedule was designed with formal sessions on one full day each week, thereby maximising the time spent 'on task', while other days were set aside for additional support (mentoring, business clinics, events and

\footnotetext{
${ }^{1}$ This has now been superseded by QAA (2018).
} 
team work) and for students to develop their ventures through work-based modules, thereby maximising engagement and, hopefully, student outcomes within the curriculum (Lingard 2007; Mioduser et al. 2002).

\section{Programme structure}

The approach and pedagogy positioned the VCP to develop both the student learner and their business. Therefore, the 3-year programme was split into two streams which focused on:

1. The entrepreneur and

2. The business venture.

In the first year the programme encouraged ideation and venture creation; in the second year, this moved aside to facilitate a focus on marketing, sales and cash flow stabilisation, while the third year was centred around business growth, innovation and investment. The programme was designed to provide flexibility in the final year so that students could tailor their modules and assessments to suit the needs of their developing businesses. These negotiated modules allowed the students to formulate the learning outcomes over the module, recognising that even at this stage both business and personal needs might rapidly develop.

This was complemented by the learning environment provided by the university, consisting of not just the classroom but also space whereby students could develop their businesses. Every student was therefore provided a place in the university's business incubator, and they have access to this for the duration of the programme. This location acted as a hub for the broader entrepreneurial student community to engage with the students on this programme. The development of a community (Zimmer 1986; Kilkenny et al. 1999) around the programme was seen as very important in embedding the students within the local business ecosystem. The cornerstone of this strategy was recruiting 15 Entrepreneurs in Residence (EiR) from a diverse range of businesses. These business owners acted as entrepreneurial role models (Bosma et al. 2012; Lafuente et al. 2007) as it has been shown as an important factor in the decision to start and influence (Van Auken et al. 2006) the growth of businesses.

In order to foster an authenticity of experience all of the modules within the programme were taught by experienced entrepreneurs (Hopkins and Feldman 1989) with further engagement from local business practitioners who provided mentoring and other associated support. These role models added to the student experience while supporting the practice-oriented pedagogical approach.

The programme is structured around $50 \%$ of the credits each year being achieved from work-based learning (WBL) modules (Boud and Solomon 2001; Raelin 1997) which is supporting the application of the knowledge developed within the taught modules. This structure is now explored. 


\section{Taught modules}

Table 1 provides a breakdown of the taught modules and how they were divided between the two streams. In these, first-year students as entrepreneurs develop their mindset and communication skills, while for their business, the process of starting a business and developing a plan. In the second year they develop leadership skills, financial management, advertising, sales and a negotiated learning outcomes module. In the final year, as an entrepreneur the curriculum is focused on decision making, performance and innovation management, and the business focused modules develop growth through marketing and international trade.

\section{Work-based modules}

The work-based modules (shown in Table 2) and simulated projects were seen as crucial to the development of core venture skills (Timmons and Spinelli 1999; Zhong-wei 2008) and reflective capacity (Jack and Anderso 1999; Harvey and Evans 1995) linking the theory and practice of entrepreneurship together in practical endeavours. These were structured with varying levels of staff intervention to match the progression of the students. In earlier years there was a greater element of 'control' (Jones et al. 2014) and risk mitigation managed by staff to provide a 'safe space' (Jones et al. 2014) in which the students could experience failure and be guided through the process. As they progress through the degree, these 'training wheels' were progressively removed and students were challenged in a number of new ways including having to negotiate learning outcomes for modules and contented with new assessment challenges alongside the growth of their ventures. Each module required the students to complete a journal of critical reflections (Cope and Watts 2000; Mezirow 1990) addressing their experiences at regular intervals, bring together the concept of entrepreneurial moments or learning events, especially when initially viewed as discounted (Cope 2003) these series of reflections support the development of higher-level learning. This was used to provide a consistent longitudinal vehicle for reflection of their development throughout the programme.

\section{Assessment strategy}

Assessment strategies in higher education have been experiencing a period of diversification (Fry et al. 2008) and best practice development (Rust 2002), meaning that a number of sources are available to inform strategic approaches. For example, Pittaway and Edwards (2012) highlighted several innovative assessment practices which could be used within these types of programme, and these included self-assessment and peer assessment. Carey and Matlay (2010) also highlighted best practice assessment strategies from the creative industries which could be applied to entrepreneurship education. Both studies developed the importance of industry or degree 


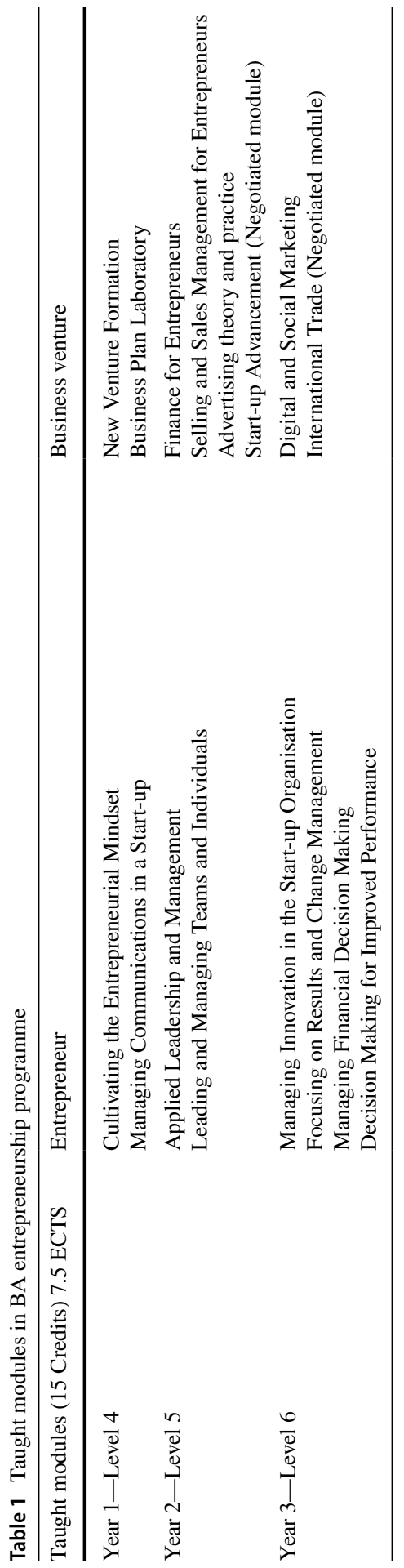


Table 2 Work-based learning modules in BA entrepreneurship programme
Work-based learning modules (20

Credits/10 ECTS)

\begin{tabular}{ll}
\hline Year 1-Level 4 & $\begin{array}{l}\text { Team-based Incubation Project } \\
\text { Business Start-up Research }\end{array}$ \\
Year 2-Level 5 & $\begin{array}{l}\text { Business Operations } \\
\text { Customer Acquisition }\end{array}$ \\
Year 3-Level 6 & $\begin{array}{l}\text { Negotiated Module } \\
\text { Investment Readiness/Growth Project }\end{array}$ \\
\end{tabular}

Fig. 1 Distribution of assessment type across the programme

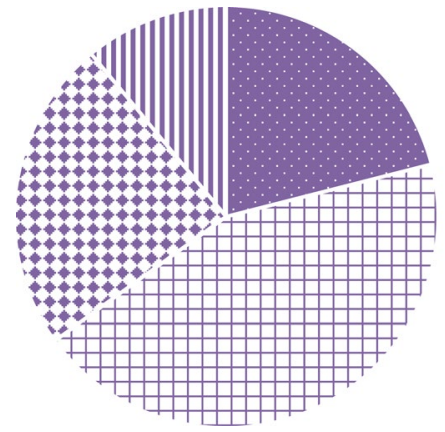

Assessment Type

an Journal, $21 \%$

+ Report/Plan, $44 \%$

: Presentation, 24\%

" Case Study, $11 \%$

community in the assessment process and that examinations were not always appropriate for entrepreneurship education.

Across the programme a mixture of assessment types were utilised in order to maximise opportunities for all students to perform and develop skills relevant to both future study and/or venture development. This was done in conjunction with maintaining the constructive alignment of the programme by developing individual competency aligned to the development of the students venture. It was important to use both a diverse and a consistent set of assessment types throughout the programme. A consistent set of assessments allowed the students' development to be meaningfully measured and also ensured the students' ability to master this assessment type was supported and evidenced. A diverse set of assessments helped to challenge the students' development and provided the opportunity for them to evidence their learning in different contexts which was a key part of the degree's philosophy. Consequently, this programme used assessment 'for' learning as well as assessment 'of' learning (Gibb 1993, 2011) with a clear view to ensure inclusivity. Figure 1 demonstrates the mixture of assessments types used on the programme.

This programme did not use examinations as an assessment type as this was highlighted in a number of papers, such as Pittaway and Edwards (2012) and Carey and Matlay (2010) that it may not be conducive to an academic environment where students were trying to develop original ideas, articulate these, and had them assessed, especially when considering the implementation of constructive alignment. Through their removal the authors felt that they had moved a step closer to our pedagogical ambition of developing a more coherently aligned (Biggs 2000) learning environment which more closely mirrored the realities of entrepreneurial endeavours. This 
Table 3 Key pedagogical reflections

\begin{tabular}{|c|c|c|c|}
\hline & Positive & Neutral & Negative \\
\hline Curriculum & Programme structure & & \\
\hline Teaching methods & & Virtual learning spaces & Student engagement \\
\hline Learning environment & Degree community & & Learning communities \\
\hline Assessment procedure & & Reflective practice & \\
\hline
\end{tabular}

was achieved by supporting entrepreneurial learning activities that were appropriate to the students' context and educational needs and adapting those which were not. For example, prior to the VCP all of the Law and Accounting modules accredited for use in the Business School used examinations as the main assessment type as it was an external requirement and, therefore, careful selection of and/or re-purposing of the modules was needed to ensure they aligned to the programmes philosophy and design.

This required the design of the assessment which was based on the student's own business and not simply a case study example. The assessments then became fundamental to the development of the student's venture as they provided staged points by which the student's own development and understanding was evaluated.

\section{Analysis}

This analysis of an early-stage evaluation of a programme was using the methodology proposed by Kirkpatrick focusing on level 1 and level 2 of the evaluation framework. To accomplish this the authors took materials gathered and their own reflections (diaries, journals, etc.), student assessment data, student's reflection journal and added to this with feedback from the students, colleagues and the external examiner. This process led them to identify three groups of reflective data which emerged as the data were collected:

1. Positive reflections-reflections where content and experience were generally positive;

2. Neutral reflections - reflections where content and experience were mixed; and

3. Negative reflections-reflections where content and experience were generally negative.

From these three groups six elements began to coalesce, and these were presented as key learning moments (Rae 2012) using the commonly experienced events which have been encountered within the entrepreneurship learning in the first year of the degree. These addressed important concerns, challenges, achievements, and realisations which have affected the programme and will have a distinct impact on its future form and direction (Table 3 ) when the level 3 and 4 analysis is conducted.

These six key pedagogical elements will now be discussed in more detail. 


\section{Programme structure}

When the authors compared VCPs across the world (Lackéus and Williams-Middleton 2018) there seemed to be an accepted balance between the time spent in the classroom and the time spent focusing on the learner's venture. Therefore $50 \%$ of the module credits were from work-based learning and $50 \%$ from academic study and scholarly activities, aligning the teaching methods to the curriculum. This created a clear narrative focusing the student to work in and on their business, developing the core philosophies of the programme throughout.

The taught element was scheduled on the same day each week (Wednesday for first years), so that students could maximise the time spent on their business while also having dedicated space to study and develop their other skills. Tuesday was set aside to support work-based learning, which included webinars, business clinics and mentoring sessions. Friday was used for trading exercises. The students liked this arrangement and most attended Tuesday and Wednesday throughout the year. Those who did not attend the Tuesday's programme gained support via webinars and telephone mentoring.

To deliver the range of teaching methods the course required a programme team who could facilitate the learning environment and understand the alignment required for successful implementation within a VCP. The team was made up of one programme leader, one enterprise manager, and six part-time staff, all of whom had entrepreneurship experience in starting and running businesses and, therefore, were academic entrepreneurs (De Silva 2016). The part-time members were also practising entrepreneurs who were portfolio working with a proven academic teaching background. The diversity of their backgrounds and current experience encouraged the students to develop greater empathy and respect with the teaching team from the offset. This supported the interactions with the wider degree community and role models for the reflective practice.

Setting out a clear structure, timetable and expectations from the start provided a set of assumptions which the students understood and also appreciated. This generated positive feedback on open days and through the 1-2-1 academic tutoring sessions where students discussed planning their time and business meetings. This 'learning agreement' was seen as one of the core successes between the student and programme as it provided a basis for understanding and development (both student and programme) from which both parties could move forward with over the three years.

In summary, to ensure the VCP structure had constructive alignment and fulfilled the goals of a VCP, the curriculum was designed around the starting and growth stages of a business; the teaching used a mixture of professional entrepreneurs and educators; and the innovative learning environment was based around the physical spaces and the strong interactions between the local entrepreneurial business community. 


\section{Pedagogical implications}

- Setting student expectations from the start (recruitment) provided students with a known schedule and business like interactions; and

- Developing a personal learning agreement which ensured students could balance learning, their business, and personal life ensured that students received the attention they required and understood the academic development time they must manage.

\section{The degree community}

Moore (2012) suggested that education may be as much about social engineering as about personal empowerment. This within an action-based entrepreneurship education programme means that we need integrate the programme pedagogy with the local entrepreneurial ecosystem to encourage the development of a social community around the programme.

Initially, we developed the Worcestershire entrepreneurship ecosystem map and shared this with stakeholders, and this promoted awareness of what was happening throughout the region while simultaneously promoting our programme. Every one of the 200 organisations on this map we had a working relationship with. The map used the structure and findings from the Babson entrepreneurship ecosystem project research (Fetters et al. 2010; Isenberg 2010, 2011) to develop the entrepreneurial capacity in defined localities; bringing together the policies, structures, programs, and climate that foster entrepreneurship. This tool was used in a number of ways:

- Mentoring Sessions: The map was provided to all mentors, so they could provide a consistent narrative and discussion on the available entrepreneurial ecosystem support and also discuss openly what was available with the mentee; and

- Business Clinics: When discussing any one aspect of support which was being supplied, we could first show the entire ecosystem before drilling down into the details of one aspect. This ensured that the students could gain an understanding of the whole.

Mentoring was an important element within the portfolio of pedagogy constructs within the programme. Mentoring has been shown (St-Jean and Audet 2012) to develop cognitive and affective learning as well as provide additional experience and competency for the novice entrepreneur. The development of the affective or emotional areas supports their development of self-awareness (Bacigalupo et al. 2016) and entrepreneurial self-efficacy (Chen, et al. 1998) which have been shown to be key factors in developing high-performance entrepreneurs. To support this, positions were advertised for volunteer Entrepreneurs in Residence (EiR) to provide support to the programme and the team, and we received seven applications. Each was assessed using a practical interview process which consisted of a networking event with staff and current students who were starting a business. The criteria used were from Bushardt et al. (1982) which states (1) that person can help you, (2) he or she 
has your confidence, (3) you can help that person, and (4) he or she has a successful track record of mentorship. Students and staff were asked to provide feedback based on these criteria. This event proved very successful, and we decided to take all those that applied, the only issue being there was a limited diversity. At the end of the first year of operations we had 15 EiRs who were from very diverse industries with backgrounds and experience. As a group they had a broad and varied network which supported the introduction to almost all businesses within the country and these contacts had benefited the students.

These individuals' mentored the students, provided weekly business clinics and a Q\&A forum service. All students were offered at least one mentor to support their personal growth, one mentor (Megginson 2006) to support the developmental stage of their business, and another to provide local support relating specifically to the industry or physical location of their business. They also had 1-2-1 skills development such as telephone cold-calling skills, business process mapping, and even gone with students to supplier meetings.

Perhaps, most importantly, these people provided invaluable links between the university and the local business community helping the students to network and integrate. This was evidenced by one student's comments 'One of the best things I've got out of this course so far is the amount of access to key people in my industry. The connections I make on a weekly basis through the BA in entrepreneurship course are incredible.' The EiRs in the first year of operation invested financially in the entrepreneurship cohort and also in other university graduates, which has also been shown by Schwarzkopf et al. (2010).

The diversity of the students, their ideas and their business requirements could not be met by one person or a single organisation and it was only through this community that educators could provide the ultimate student experience and learning outcomes. It was no longer acceptable to just manage a classroom experience. In entrepreneurship there was very often conflicting advice and views and it was only through knowledge, mentoring, experimentation and experience that a way could be found for the individual student entrepreneur.

\section{Pedagogical implications}

- The development of a cohort of mentors provided numerous benefits as it allowed the education ecosystem to extend from the classroom, to those supporting the students and the wider business community; and

- The development of a simple programme philosophy which could be shared and understood by all stakeholders ensured wider buy in within a greater community.

\section{Reflective practice}

The programme assumes that learning is best when it is active, when it incorporates experience and when it can be shared and supported through collaboration. As such, our pedagogy focus is on problem-based learning (Hung, Jonassen and Liu 2008), use of authentic assessment and reflective writing (Kakouris 2015; Jack and 
Anderson 1999; Harvey and Evans 1995) to develop a lifelong learning approach for our entrepreneurial students.

Critical reviews of the assessment strategies used in universities and of reflective practice in general (Elton and Johnston 2002; Findlay 2008; Palomba and Banta 1999) assert that reflection and reflective practice are lacking in the development of a large number of students, but that this can be difficult to encourage as it requires the development (on the students part) of a broad range of skills and faculties to enable them to engage with the process effectively.

This use of reflective journals in the development of professional best practice, especially in the disciplines of Nursing and Education, has been embedded within the curriculum for many years, as it encourages students to integrate theory with practice, appreciate the world on their own behalf, and turn every experience into a new potential learning experience (Wong et al. 1995).

With that in mind it was decided that a reflective journal would be used in the two work-based learning modules each of the three years. To support this, reflective writing sessions were also added to several modules, even those which occurred relatively early in the students learning journey in an attempt to maximise their exposure and normalise the experience. Eventually, these were linked together using the VLE's journal entry subsite using additional material and videos to create an information hub from which students could draw support, advice and guidance.

Based on this work, a number of students began to adopt the habits of a reflective practitioner early in the programme and developed a useful weekly reflective journal which, they felt, supported their entrepreneurial development. These students were getting feedback from four members of staff on a regular basis and, in their writing, acknowledged the benefits that reflexivity had on their learning and also on the development of their businesses.

However, there were a group of students for whom reflection did not come so naturally and further development was required. This, in itself, was a 'reflection' on the nature of reflective practice; it was a lifelong process and an experiential one (Kolb and Kolb 2005) through which individuals were developing and redeveloping learning. No one student approached it from the same starting point, and most required different levels of support to achieve something meaningful. This meaned that even with support de-engagement could be difficult to avoid, in this context it was apparent through poor-quality reflections and a lack of development in some members of the student population.

After speaking to the affected students about the reasons why they did not fully engage with the reflective processes we identified several issues. The first was about being judged, both personally and professionally, something which they at times found difficult to accept. The second was that the students' personal lives could take priority over both academic and business development and they found this difficult to share this as they believed it would affect their marks adversely to admit difficulties. At the core of both of these points there was a powerful realisation for the course team that some students did not engage fully with reflective writing because they simply found it difficult to be 'right' and present a positive image of themselves and their endeavours rather than doing, what they felt, was dwelling on the negatives. 
With this in mind the team planned to add mid-module review sessions both in class and individually during personal tutoring sessions. These discussions would have been directed towards how reflective practice could support the students learning and ultimately their effectiveness (QAA 2012, 2018) as an entrepreneur but only as part of an honest and forthright process.

Recognising that business school staff were not good at developing reflective practice, we intended to use a professional reflective and reflexive facilitator (from a different subject area such as Nursing or Education) who would organise regular individual and group sessions and more informal review sessions where students would have discussed reflective issues and investigated different ways of approaching their reflective practice.

\section{Pedagogical implications}

- Reflective practice is a critical part of the development of a practitioner and as such should be an integral part of the assessment and development of the entrepreneur. However, its integration requires insight from other disciplines in which reflection is common practice; and

- A clear process of support and reflective development is required to ensure the development of a successful reflective practitioner.

\section{Virtual learning spaces}

Beetham and Sharpe (2013) state that digital technology is 'Like previous innovations, they can be assimilated to pedagogical practice without altering the fundamental truths about how people learn'. The amount of content which is available in digital form has increased, and the ability for students to access this on multiple devices ensures numerous learning opportunities both within and outside the classroom.

It was therefore decided that a key element of the degree was the use of virtual learning spaces such as the university's VLE (Blackboard) to host material including pre-recorded lectures, sessional activities, reading and extensions tasks. The idea behind this was to allow for 'flipped' (Sams and Bergmann 2013) approach to learning through both online and in class delivery maximising the one day that students had on campus by extending the learning environment beyond this physical limitation allowing for more delivery via video or audio, for example.

To facilitate this, early in the degree design process, formats for delivery were created and circulated, VLE areas were established, and best practice was shared between staff. However, while some lecturers championed the format, some resisted this because of time, comfort or technical skills. This immediately sent mixed messages to the students as delivery and experience were not consistent. As a result, some disengaged with the process at this stage and only re-engaged sporadically or when forced to for assignments meaning that key elements of the 'flipped' programmes had to be re-calibrated at the last minute to ensure that students who were not engaging online did not miss any delivery. This in turn led to repetition and also 
frustration for the students who as 'early adopters' had engaged fully with the online experience.

Having spoken to staff and students it became clear that students saw the VLE as a positive, but the mixed delivery methods were confusing and staff saw it as too time-consuming even given the formatting help and support that was provided to them. However, the first year of a module had considerable amount of development and subsequent years had less.

To mitigate this risk the team intended to provide a video introduction for the students on how to use the VLE within the programme homepage and additional support during the sessions throughout the year. Also, there were intentions to experiment with a 'flipped light' version of the delivery process to create a lower bar for staff to achieve while retaining a consistent approach across the teaching team; this would be more of a blended approach allowing staff with the skills to do more and staff who found it difficult to be supported and take other routes to achieving an engaging product. The use of the VLE, learning technologists, video creation support, and peer educator support through the programme delivery team was an important development for the programme, which has been used subsequently during the planning of the Covid-19 response. The key to this would be that it was made clear to the students how each module would approach the issue and that this would remain consistent across the delivery of that module.

Based on student feedback it was also decided to deliver one of the first modules in the programme via a portfolio assessment based solely within the VLE. Everyone hoped that this would ensure that the students engaged within the VLE more fully during the crucial early part of the degree. To achieve this, we had planned a structure which meant that the students would be fulfilling regular tasks towards their assignment promoting engagement, familiarity and development within the structure.

\section{Pedagogical implications}

- The professional development of the teaching team so as to provide a consistent pedagogy approach within the VLE; and

- A dedicated session to introduce the VLE and the benefits of using it for students.

\section{Learning communities}

A learning community has been defined as 'an intentionally developed community that exists to promote and maximise the individual and shared learning of its members (Beck and Foster 1999). They provide an ongoing interaction, relationship, and collaboration among the community's members as they work towards a specified common learning goals' (Lenning et al. 2013, p. 7). Learning communities offer learning of an interactive nature and targeted to develop multiple social dimensions, such as employability, general enterprise awareness, 
intrapreneurship, and venture creation, all of which are becoming a major metric within today's UK education environment.

The team-based project module began in the first-year induction week so that insurance and other logistics could be resolved before the teams moved forward. Students were provided with a module manual which detailed the structure of the module including the standard module information plus additional information such as company structure, insurance requirements, locations, programme timings, team processes, and contact details. However, the module itself did not start until late October, a month, or so later. The delay had been designed to allow the student to gain some theoretical knowledge from the venture creation module which it was felt might support the group work; however, because the link between theory and practice was not yet clear in the students' minds a lot of this work was wasted as they did not really see how the elements linked together.

This 'gap' in delivery was further compounded by new students joining the programme late and others leaving it within the first few weeks of term all of which meant that the team formation processes were never really completed; this led to a lack of team structure within the groups throughout the module.

Additionally, the selection of products to sell on the market stall was left up to the teams. This created problems as the team were newly formed and personalities dictated what got sold and not a logical approach based on customer needs and market demand. Each team purchased stock to sell which never sold and detracted from the core tasks of the module of sales and marketing and led the team into a negative mindset and leadership issues.

Finally, the leadership of the groups moved from one person to another as the module progressed and it was clear that this enabled the team to use the skills to their advantage but also shifted responsibility from one to the next without a clear set of reflections on what went wrong.

It was evident that teamwork and this group-based assignment needed further development. Therefore, as part of the wider curriculum review, a research project was developed across all entrepreneurship modules to evaluate how to improve entrepreneurship team-based modules which consisted of 131 students. The core findings of the research project have led to the following future actions for this team-based project modules:

- A lecture session and video were created to introduce the teamwork aspects of the students. Three core aspects will be covered, (1) what makes a good team member (2) what makes a good team, and (3) why good teams get good marks;

- A team-building activity will be built into the module. Once this is concluded, no other members will be allowed to join;

- Team size will be between two and four people, starting with four;

- Facebook will be used for internal communications from the start. (The groups which used this were more successful in their grades);

- It is intended to use a similar system as in the Apprentice TV programme, where a limited selection of products will be presented to the teams and they then pitch for and then buy the products using their own money; and 
- A monthly formal board meeting in our boardroom whereby the company reports to the shareholders and publishes minutes. These will then form part of the formative assessment. Non-attendance and non-contribution then get reported regularly.

\section{Pedagogical implications}

- A more structured implementation of the learning communities provides students with how to be a productive member and what others expect from them; and

- Making the learning community report their actions ensure that all members are engaged in this action-based education.

\section{Student engagement}

Engagement has emerged as a key metric measure (Kahu 2013) of higher education impact over the last decade. It has become a catch-all term most commonly used to describe a compendium of behaviours characterising students who are said to be more involved with their university community than their less-engaged peers. Engagement refers to the time, enthusiasm, and resources students devote to activities both in and outside the curriculum to enhance learning while at university. Therefore the pedagogy design of our programmes requires a range of activities which include lectures, tutorials, online VLE, webinars, personal academic tutoring, team activities, through to mentoring, business clinics, and events which align with the needs of the student and also the learning outcomes.

Ahlfeldt, Mehta, and Sellnow (2005) found that the level of engagement was typically higher in those classrooms with more problem-based learning (PBL) and that engagement increases as programme level increases. As a result it was expected that as the programme was targeted to encourage learning 'for entrepreneurship' (a PBL approach), it would have a better result, but because there had only been a completed a first year, this might be balanced by students 'finding their feet' and not yet fully engaging.

It was expected that truly entrepreneurial students will be hard to keep in a classroom and, as a result that we might find it more difficult to foster a learning community. However, we did not anticipate:

- One student in week three gained a contract for $£ 18,000$ which meant they were away in South East Asia for over one month;

- Two students had childcare issues for over one month which were the result of student loans being delayed;

- One student had to go and manage their father's estate after being incapacitated, so they left for another month; and

- One student was diagnosed with diabetes and learning difficulties and had over one month off dealing with these issues. 
Student engagement is not a static metric and nor is it a single entity which can be easily quantified. The level of engagement changes on a weekly basis and student engagement is physically, mentally, and also virtually. Therefore, student engagement has to be measured and evaluated continuously to gain feedback and develop an ongoing understanding of the situation. The tools used included virtual learning environment, surveys session sign in sheets, class appraisals, posit-it feedback, module evaluation, personal academic tutoring and programme meetings.

As in many programmes there was a direct correlation between those attending classes and the grades achieved at the end of the year. Extra-curricular activities were attended by around $50 \%$ of the students on a weekly basis which for some programmes was extremely high, but as it was part of a work-based learning programme, it was felt this could be improved.

To develop both higher student engagement and also be able to monitor this in a less intrusive manner:

- The extra-curricular activities had been planned to be added to the reflective journal so that it was part of the assessment, rewarding good behaviour early on in the programme, and developing good habits;

- The first year, first semester Mindset module would use a portfolio assessment which would require students to attend each session to be able to complete the portfolio. This would ensure students were active throughout the first semester and engaged in this innovative and thought provoking module; and

- Mentoring sessions would require the completion of form which highlighted the tasks the student would complete before the next session. This would be handed into the enterprise manager, uploaded to the VLE and followed up before the next mentoring session.

\section{Pedagogical implications}

- The use of extra-curricular and in-curricular activities to provide a reflective portfolio for the student to develop good habits and assessment material; and

- The use of portfolio assessments within the first year provided an opportunity to build a better rapport and learning relationship with the student.

\section{Conclusions}

This paper reviewed the pedagogy used to deliver a 'true' Venture Creation Programme (VCP) at the University of Worcester. This practice-oriented degree combined the creation of a functioning venture with academic study (Lackéus and Williams-Middleton 2018). Therefore, the purpose of the paper is to provide a critical overview of the ways in which learning can be facilitated through VCPs and focused on six core aspects of pedagogy: the programme structure, degree community, reflective practice, virtual learning spaces, learning communities and student engagement. 
The structure is the first stage in developing a constructively aligned programme, and this was done by setting the programme definitions, taught schedule, and the use of academic entrepreneurs (Hopkins and Feldman 1989). However, for a successful implementation the alignment of the students' expectations was critical, especially within a VCP that was creating an environment where managed discourse and opportunity development were the norm. This was a twoway accord with the learning agreement ensuring the commitment from the student. The programme structure must be the stabilising core for all those involved with the VCP, especially the students and the wider business community.

The aim of this degree community was to provide a seamless ecosystem of support to the students and was essential in building self-efficacy through mentoring and business opportunities through networking. However, this community needed to gain awareness and understanding of the programme and this had to be done through regular communications. In our case we provided a single programme approach which successfully allowed a wide range of stakeholders to engage.

The reflective practice of an entrepreneur is an important aspect for the development of lifelong learning and aligns with our pedagogic focus on problem-based learning. Reflective practice has been widely developed in several other disciplines, and therefore, the authors drew on this to propose the use of multidisciplinary teams to develop the effective entrepreneur reflective practitioner. The majority of the reflection was done within the virtual learning spaces as part of an assessment. The virtual learning spaces provide a considerable opportunity to develop resources for students on a VCP. However, the induction for a student starting to use it and the multidisciplinary staff developing material for it, requires considerable thought and management of initially the students, staff and the technology.

The use of learning communities within a VCP provides a considerable opportunity for students to work in teams for their greater interaction, relationship, and collaboration among the course members. However, this requires a structured implementation, such as induction sessions, regular reporting, and team-building activities for it to be successfully implemented. Student engagement within a true VCP requires a number of tools to build the attendance habit early on, such portfolio assessment within the first semester first year. The development of extra-curricular and in-curricular activities throughout the years provides additional incentives to attend and also engage, providing advantages in terms of education attainment and venture creation.

In summary, this paper provides an important insight to the broader ongoing discussion surrounding the development of experiential entrepreneurial education programmes, especially contributing to the development approach of new true VCP and the critical issues around their design. The paper also focuses on how ensuring constructive alignment is a strategic aspect of the pedagogy design for the success of a VCP and its students.

Authors' contributions All authors participated in data collection and analysis including writing and approving the manuscript for submission. 
Funding Not Applicable

\section{Compliance with ethical standards}

Conflicts of interest All authors declare that we have no conflict of interest.

\section{References}

Ahlfeldt, S., Mehta, S., \& Sellnow, T. (2005). Measurement and analysis of student engagement in university classes where varying levels of PBL methods of instruction are in use. Higher Education Research and Development, 24(1), 5-20.

Bacigalupo, M., Kampylis, P., Punie, Y., \& Van den Brande, G. (2016). EntreComp: The entrepreneurship competence framework. Luxembourg: Publication Office of the European Union.

Beck, L. G., \& Foster, W. (1999). Administration and community: Considering challenges, exploring possibilities. In J. Murphy \& K. S. Louis (Eds.), Handbook of research on educational administration (pp. 337-358). San Francisco: Jossey-Bass.

Beetham, H., \& Sharpe, R. (Eds.). (2013). Rethinking pedagogy for a digital age: Designing for 21st century learning. UK: Routledge.

Biggs, J. (1996). Enhancing teaching through constructive alignment. Higher Education, 32(3), 347-364.

Biggs, J. (2000). Aligning teaching for constructing learning. York: Higher Education Academy.

Bird, B. J. (1995). Towards a theory of entrepreneurial competency. Advances in Entrepreneurship, Firm Emergence and Growth, 2, 51-72.

Bosma, N., Hessels, J., Schutjens, V., Van Praag, M., \& Verheul, I. (2012). Entrepreneurship and role models. Journal of Economic Psychology, 33(2), 410-424.

Boud, D., \& Solomon, N. (2001). Work-based learning: A new higher education?. UK: McGraw-Hill Education.

Bozward, D., \& Rogers-Draycott, M.C. (2017). Developing a staged competency based approach to enterprise creation. In 10th international conference for entrepreneurship, innovation, and regional development, 31st August-1st September, Thessaloniki, Greece.

Bruyat, C., \& Julien, P. A. (2001). Defining the field of research in entrepreneurship. Journal of Business Venturing, 6(2), 165-180.

Bushardt, S. C., Moore, R. N., \& Debnath, S. C. (1982). Picking the right person for your mentor. Advanced Management Journal, 47(3), 46-51.

Carey, C., \& Matlay, H. (2010). Creative disciplines education: A model for assessing ideas in entrepreneurship education? Education + Training, 52(8/9), 694-709.

Chen, C. C., Greene, P. G., \& Crick, A. (1998). Does entrepreneurial self-efficacy distinguish entrepreneurs from managers? Journal of Business Venturing, 13(4), 295-316.

Clark, B. R. (1995). Places of inquiry: Research and advanced education in modern universities. California: Univ of California Press.

Cope, J. (2003). Entrepreneurial learning and critical reflection: Discontinuous events as triggers for 'higher-level learning. Management learning, 34(4), 429-450.

Cope, J., \& Watts, G. (2000). Learning by doing-an exploration of experience, critical incidents and reflection in entrepreneurial learning. International Journal of Entrepreneurial Behavior and Research, 6(3), 104-124.

De Silva, M. (2016). Academic entrepreneurship and traditional academic duties: Synergy or rivalry? Studies in Higher Education, 41(12), 2169-2183.

Dressel, P.L., (1980). Improving degree programs: A guide to curriculum development, administration, and review.

Elton, L. R. B., \& Johnston, B. (2002). Assessment in universities: A critical review of research. York: Higher Education Academy.

Farmer, S. M., Yao, X., \& Kung-Mcintyre, K. (2011). The behavioral impact of entrepreneur identity aspiration and prior entrepreneurial experience. Entrepreneurship Theory and Practice, 35(2), $245-273$.

Fayolle, A. (2007). Entrepreneurship and new value creation: The dynamic of the entrepreneurial process. Cambridge: Cambridge Press. 
Fayolle, A., Gailly, B., \& Lassas-Clerc, N. (2006). Assessing the impact of entrepreneurship education programmes: A new methodology. Journal of European Industrial Training, 30(9), 701-720.

Fetters, M., Greene, P. G., \& Rice, M. P. (Eds.). (2010). The development of university-based entrepreneurship ecosystems: Global practices. UK: Edward Elgar Publishing.

Finlay, L. (2008). Reflecting on reflective practice. PBPL paper, 52, 1-27.

Fry, H., Ketteridge, S., \& Marshall, S. (2008). A handbook for teaching and learning in higher education: Enhancing academic practice. UK: Routledge.

Gibb, A. A. (1993). Enterprise culture and education: understanding enterprise education and its links with small business, entrepreneurship and wider educational goals. International Small Business Journal, 11(3), 11-34.

Gibb, A. (2002). In pursuit of a new 'enterprise' and 'entrepreneurship' paradigm for learning: Creative destruction, new values, new ways of doing things and new combinations of knowledge. International Journal of Management Reviews, 4(3), 233-269.

Gibb, A. (2011). Concepts into practice: Meeting the challenge of development of entrepreneurship educators around an innovative paradigm: The case of the international entrepreneurship educators' programme (IEEP). International Journal of Entrepreneurial Behavior and Research, 17(2), 146-165.

Harvey, M., \& Evans, R. (1995). Strategic windows in the entrepreneurial process. Journal of Business Venturing, 10, 331-347.

Hopkins, T., \& Feldman, H. (1989). Changing entrepreneurship education: finding the right entrepreneur for the job. Journal of Organizational Change Management, 2(3), 28-40.

Hung, W., Jonassen, D. H., \& Liu, R. (2008). Problem-based learning. Handbook of research on educational communications and technology, 3, 485-506.

Isenberg, D. J. (2010). How to start an entrepreneurial revolution. Harvard Business Review, 88(6), 40-50.

Isenberg, D. (2011). The entrepreneurship ecosystem strategy as a new paradigm for economic policy: Principles for cultivating entrepreneurship. Dublin: Institute of International European Affairs.

Jack, S. L., \& Anderson, A. R. (1999). Entrepreneurship education within the enterprise culture: Producing reflective practitioners. International Journal of Entrepreneurial Behavior and Research, 5(3), 110-125.

Jones, C., Matlay, H., Penaluna, K., \& Penaluna, A. (2014). Claiming the future of enterprise education. Education Training, 56(8/9), 764-775.

Kahu, E. R. (2013). Framing student engagement in higher education. Studies in Higher Education, 38(5), 758-773.

Kakouris, A. (2015). Entrepreneurship pedagogies in lifelong learning: emergence of criticality? Learning, Culture and Social Interaction, 6, 87-97.

Kilkenny, M., Nalbarte, L., \& Besser, T. (1999). Reciprocated community support and small town-small business success. Entrepreneurship and Regional Development, 11(3), 231-246.

Kirkpatrick, D. L. (1975). Education training programs. New York: Tata McGraw-hill education.

Kirkpatrick, D. L., \& Craig, R. L. (1970). Evaluation of training. In P. L. Browning (Ed.), Evaluation of short-term training in rehabilitation (pp. 35-56).

Kolb, D. A. (1984). Experiential learning: Experience as the source of learning and development. Englewood Cliffs: Prentice-Hall Inc.

Kolb, A. Y., \& Kolb, D. A. (2005). Learning styles and learning spaces: Enhancing experiential learning in higher education. Academy of Management Learning and Education, 4(2), 193-212.

Kuratko, D. F., Morris, M. H., \& Schindehutte, M. (2015). Understanding the dynamics of entrepreneurship through framework approaches. Small Business Economics, 45(1), 1-13.

Lackéus, M. (2016). Value creation as educational practice-towards a new educational philosophy grounded in entrepreneurship?. Chalmers University of Technology (Doctoral dissertation).

Lackéus, M., \& Williams-Middleton, K., (2011). Venture Creation Programs: entrepreneurial education through real-life content. In Babson college entrepreneurship research conference (pp. 1-16).

Lackéus, M., \& Williams-Middleton, K. (2015). Venture creation programs: Bridging entrepreneurship education and technology transfer. Education + Training, 57(1), 48-73.

Lackéus, M., Williams-Middleton, K., \& Lundqvist M. (2018). Venture creation programs list I we list venture creation programs. [online] http://vcplist.com [Accessed 29 Apr 2018].

Lafuente, E., Vaillant, Y., \& Rialp, J. (2007). Regional differences in the influence of role models: Comparing the entrepreneurial process of rural Catalonia. Regional Studies, 41(6), 779-796.

Le Deist, F. D., \& Winterton, J. (2007). What is competence? Human Resource Development International, 8(1), 27-46. 
Lenning, O.T., Hill, D.M., Saunders, K.P., Solan, A., \& Stokes, A., (2013). Powerful learning communities: A guide to developing student, faculty, and professional learning communities to improve student success and organizational effectiveness. Stylus Publishing, LLC.

Lewy, A., (1977). Handbook of curriculum evaluation. Lewy, Arieh, Ed

Lingard, B. (2007). Pedagogies of indifference. International Journal of Inclusive Education, 11(3), 245-266.

Man, T. W. Y. (2007). Understanding entrepreneurial learning: A competency approach. International Journal of Entrepreneurship and Innovation, 8(3), 189-198.

Megginson, D. (2006). Mentoring in action: A practical guide (pp. 8-13). London: Kogan Page.

Mezirow, J. (1990). Fostering critical reflection: A guide to transformative and emancipatory learning. San Francisco: Jossey-Bass.

Mioduser, D., Nachmias, R., Tubin, D., \& Forkosh-Baruch, A. (2002). Models of pedagogical implementation of ICT in Israeli schools. Journal of Computer Assisted learning, 18(4), 405-414.

Moberg, K., Stenberg, E., \& Vestergaard, L. (2012). Impact of entrepreneurship education in Denmark-2012. Odense: The Danish Foundation for Entrepreneurship-Young Enterprise.

Molenda, M. (2003). In search of the elusive ADDIE model. Performance improvement, 42(5), 34-37.

Moore, A. (2012). Teaching and learning: Pedagogy, curriculum and culture. Abingdon: Routledge.

Mwasalwiba, E. S. (2010). Entrepreneurship education: A review of its objectives, teaching methods, and impact indicators. Education + Training, 52(1), 20-47.

Ollila, S., \& Williams-Middleton, K. (2011). The venture creation approach: Integrating entrepreneurial education and incubation at the university. International Journal of Entrepreneurship and Innovation Management, 13(2), 161-178.

Osterman, K. F., \& Kottkamp, R. B. (1993). Reflective practice for educators. Newbury Park: Corwin Press.

Palomba, C. A., \& Banta, T. W. (1999). Assessment essentials: Planning, implementing, and improving assessment in higher education., Higher and adult education series San Francisco: Jossey-Bass.

Pittaway, L., \& Edwards, C. (2012). Assessment: examining practice in entrepreneurship education. Education + Training, 54(8/9), 778-800

Quality Assurance Agency (QAA), (2012). Enterprise and entrepreneurship education. Guidance for UK Higher Education Providers. UK: QAA

Quality Assurance Agency (QAA) (2018). Enterprise and entrepreneurship education. Guidance for UK Higher education providers. UK: QAA

Rae, D. (2003). Opportunity centred learning: An innovation in enterprise education? Education + Training, 45(8/9), 542-549.

Rae, D. (2012). Action learning in new creative ventures. International Journal of Entrepreneurial Behavior \& Research, 18(5), 603-623.

Raelin, J. A. (1997). A model of work-based learning. Organization Science, 8(6), 563-578.

Rasmussen, E., Mosey, S., \& Wright, M. (2011). The evolution of entrepreneurial competencies: A longitudinal study of university spin-off venture emergence. Journal of Management Studies Special Issue: Revitalizing Entrepreneurship, 48(6), 1314-1345.

Rust, C. (2002). The impact of assessment on student learning: how can the research literature practically help to inform the development of departmental assessment strategies and learner-centred assessment practices? Active Learning in Higher Education, 3(2), 145-158.

Sams, A., \& Bergmann, J. (2013). Flip your students' learning. Educational Leadership, 70(6), 16-20.

Sanchez, J. C. (2011). University training for entrepreneurial competencies: Its impact on intention of venture creation. International Entrepreneurship and Management Journal, 7(2), 239-254.

Sarasvathy, S. D., \& Venkataraman, S. (2011). Entrepreneurship as method: Open questions for an entrepreneurial future. Entrepreneurship Theory and Practice, 35(1), 113-135.

Schwarzkopf, J., Lévesque, M., \& Maxwell, A. (2010). How entrepreneurs-in-residence increase seed investment rates. Venture Capital, 12(1), 65-81.

Scott, J. M., Penaluna, A., \& Thompson, J. L. (2016). A critical perspective on learning outcomes and the effectiveness of experiential approaches in entrepreneurship education: Do we innovate or implement? Education + Training, 58(1), 82-93.

Shane, S., \& Venkataraman, S., (2007). The promise of entrepreneurship as a field of research. In Entrepreneurship (pp. 171-184). Springer, Berlin

Sortrakul, T., \& Denphaisarn, N., (2009). The evolution of instructional system design model. In The sixth international conference on elearning for knowledge-based society (No. December, pp. 17-18). 
St-Jean, E., \& Audet, J. (2012). The role of mentoring in the learning development of the novice entrepreneur. International Entrepreneurship and Management Journal, 8(1), 119-140.

Timmons, J. A., \& Spinelli, S. (1999). New venture creation: Entrepreneurship for the 21st century. New YorK: McGraw-Hill.

Tinto, V. (2003). Learning better together: The impact of learning communities on student success. Higher Education monograph series, 1(8), 1-8.

Van Auken, H., Fry, F. L., \& Stephens, P. (2006). The influence of role models on entrepreneurial intentions. Journal of Developmental Entrepreneurship, 11(2), 157-167.

Vesper, K. H., \& Gartner, W. B. (1997). Measuring progress in entrepreneurship education. Journal of Business Venturing, 12(5), 403-421.

Wong, F. K., Kember, D., Chung, L. Y. F., \& CertEd, L. Y. (1995). Assessing the level of student reflection from reflective journals. Journal of Advanced Nursing, 22, 48-57.

Zhong-wei, L. H. S. C. (2008). An empirical study of the relationships between emotional conflicts and entrepreneurship of top management team and business growth performance. Finance and Trade Research, 2, 18.

Zimmer, C. (1986). The art and science of entrepreneurship. Cambridge: Ballinger.

Publisher's Note Springer Nature remains neutral with regard to jurisdictional claims in published maps and institutional affiliations. 